\title{
Injuries in professional horse racing in Great Britain and the Republic of Ireland during 1992-2000
}

\author{
M Turner, P McCrory, W Halley
}

Br J Sports Med 2002;36:403-409

Professional horse racing is an exciting and demanding sport with high injury rates. Surprisingly few epidemiological studies have been published and no prospective studies have been reported. This paper reviews the literature and provides a detailed breakdown of injuries in Great Britain and the Republic of Ireland for 1992-2000. The introduction of protective equipment is discussed and evidence for its effectiveness put forward.

See end of article for authors' affiliations

Correspondence to Dr Turner, Chief Medical Adviser, Jockey Club, 42 Portman Square, London W1H 6EN, UK; JOCKEYDOC@aol.com

Accepted 14 August 2002
$\mathrm{H}$ orse racing is an immensely popular global sport with attendance figures exceeding all other professional and collegiate sports in the United States. ${ }^{1}$ In Great Britain, spectator numbers have regularly topped 5 million since 1997 (2 million for jump meetings and 3 million for flat meetings), and horse racing ranks second to soccer in televised coverage available to terrestrial viewers.

A review of the literature shows a paucity of information on the incidence and type of injuries suffered by professional jockeys. This review is designed to both critically appraise the available literature and provide a detailed breakdown of race riding injuries in Great Britain and Ireland for 1992-2000.

Since 1992, considerable changes have been introduced in the monitoring of race riding injuries, the type of protective equipment compulsorily worn by professional jockeys, and the medical arrangements available on racecourses. Analysis of the injury rates over this period will highlight these specific issues.

\section{BACKGROUND}

Professional horse racing is broadly divided into flat racing and jump racing (also referred to as National Hunt racing), both of which take place over a full 12 month season. Flat racing on grass is also referred to as turf flat racing. Flat racing is also conducted on "all weather tracks", which are constructed of a sand/fibre/binder combination which does not freeze during the winter months (November-March). Injury rates for turf and all weather track racing will be considered separately.

In Great Britain in the year 2000, a total of 107 flat racing jockeys and 90 jump jockeys had full registration, and 128 flat apprentices and 128 jump apprentices were registered. In addition, 462 amateur jockeys were registered for flat racing and 468 for jump racing. Male jockeys dominated the professional sport, with four female flat jockeys, 32 female flat racing apprentices, three female jump jockeys, two female jump apprentices, and 168 female amateur jockeys registered. For the same year in Ireland, 59 flat jockeys, 85 apprentice flat jockeys, and 133 jump jockeys were registered. No information is available on the sex of these riders. These rates of female jockeys are low by comparison with some US studies, which show $25-30 \%$ female participation rates. ${ }^{2}$

In Great Britain, professional horse racing is conducted on 59 racecourses ( two in Wales, five in Scotland, and 52 in England). Each racecourse is responsible for an average of 20 race meetings per annum (range 5-63), and a total of 1050 meetings were held in 2000. The highest number of meetings on any one day is 11 jump meetings and six flat meetings. In Ireland, horse racing is conducted on 27 racecourses. Each racecourse is responsible for an average of 10 race meetings per annum with a total of 270 meetings held in 2000.

The shortest flat race distance is 5 furlongs ( 1 $\mathrm{km}$ or 0.625 miles), and the longest race distance is 2.75 miles $(4.4 \mathrm{~km})$. For jump racing, the distances vary between 2 and 4.5 miles (3.2-7.2 $\mathrm{km})$.

In Great Britain, for the year 2000, racing involved 12586 horses in training, 8360 owners, and 525 trainers. For each meeting an average of 25 jockeys are in attendance (range 13-83). In the same year in Ireland, racing involved 4776 horses in training, 3500 owners, and 372 trainers.

\section{Flat jockeys and flat racing}

Flat jockeys usually start race riding at 16-18 years of age. At this stage, they are referred to as "apprentice" riders, and the period of apprenticeship is a maximum of five years. At the age of 25 (or after five years apprenticeship) the jockey must become a full professional flat jockey or retire from the sport. Full professional flat jockeys normally retire between the age of 50 and 59 .

During the study period, the maximum number of rides by a single flat jockey in one year was 998 for a full licence holder and 748 by an apprentice. The maximum number of wins by a single jockey was 155 for a full licence and 87 by an apprentice.

\section{Jump jockeys and jump racing}

The information is as for flat jockeys (above) except that young jump jockeys are referred to as "conditional" riders as opposed to "apprentice riders". Jump jockeys normally retire before they reach the age of 40 .

During the study period, the maximum number of rides per season by a single jump 
Table 1 Injury statistics 1992-2000 for flat racing

\begin{tabular}{lllll}
\hline Racing type & Rides & Falls & $\begin{array}{l}\text { Incidence of } \\
\text { falls/ride (\%) }\end{array}$ & Total injuries \\
\hline Flat racing GB & 317953 & 1323 & 0.42 & 535 \\
Flat racing Ireland & 67808 & 253 & 0.37 & 101 \\
Total & 385761 & 1576 & 0.41 & 636 \\
\hline
\end{tabular}

Table 2 Injury statistics 1992-2000 for jump racing

\begin{tabular}{lllll}
\hline Racing type & Rides & Falls & $\begin{array}{l}\text { Incidence of } \\
\text { falls/ride (\%) }\end{array}$ & Total injuries \\
\hline Jump racing GB & 232539 & 15856 & 6.8 & 2810 \\
Jump racing Ireland & 127686 & 6093 & 4.8 & 751 \\
Total & 360225 & 21949 & 6.1 & 3561 \\
\hline
\end{tabular}

Table 3 Injury rates 1992-2000 for all types of racing

\begin{tabular}{lll}
\hline Racing type & $\begin{array}{l}\text { Injury } \\
\text { incidence/ride (\%) }\end{array}$ & $\begin{array}{l}\text { Injury incidence/fall } \\
(\%)\end{array}$ \\
\hline Flat racing GB & 0.17 & 40.4 \\
Flat racing Ireland & 0.15 & 39.9 \\
Jump racing GB & 1.2 & 17.7 \\
Jump racing Ireland & 0.6 & 12.3 \\
\hline
\end{tabular}

Table 4 Comparison of injuries in all weather track (AWT) and turf flat racing in GB 1994-2000

\begin{tabular}{lll}
\hline Table & AWT racing & Turf flat racing \\
\hline Falls (\% of rides) & 0.28 & 0.42 \\
$\%$ falls resulting in injury & 38.3 & 40.4 \\
\% rides resulting in injury & 0.11 & 0.17 \\
Fall/ride ratio & 361 & 240 \\
Injury/ride ratio & 928 & 594 \\
\hline
\end{tabular}

jockey was 858 and the maximum number of wins in a single season was 245 . The corresponding values for a conditional/ apprentice were 374 rides and 51 wins. The maximum number of falls by a single jockey was 51 , and 31 for a conditional.

In jump racing there are separate events that involve two types of obstacle: hurdle and steeplechase fences. A hurdle race involves only hurdle fences, and a steeplechase only involves steeplechase fences. All jockeys normally ride over both types of fence. All fences are made of birch, spruce, and timber.

The tops of hurdle fences are required to be no more than 3 feet 1 inch $(94 \mathrm{~cm})$ above the ground. There must be at least eight hurdles in the first 2 miles $(3.2 \mathrm{~km})$ of the race and one additional hurdle for every additional 0.25 miles $(0.4 \mathrm{~km})$ of the race. Steeplechase fences vary both in height and type. Plain and open ditch steeple fences must be a minimum of 4 feet 6 inches $(1.37 \mathrm{~m})$. Water jump fences must be a minimum of 3 feet $(91.4 \mathrm{~cm})$, have a uniform depth of water 3 inches $(7.6 \mathrm{~cm})$, and the width of water to jump must be a minimum of 9 feet $(2.74 \mathrm{~m})$. There must be at least 12 fences in the first 2 miles $(3.2 \mathrm{~km})$ of a steeplechase race and at least six additional fences for every additional mile $(1.6 \mathrm{~km})$. Only one jump may be a water jump, but there must be at least one open ditch per mile of the race.

\section{Point to point}

Point to point racing is an amateur only sport that takes place between January and May each year. There are about 210 fixtures annually involving 1100 amateur riders jumping over steeplechase fences only. There have been a number of studies on injury rates ${ }^{3-9}$; however, this particular discipline will not be considered further in this paper.

\section{The horses}

Most thoroughbred racehorses weigh 1000-1200 lbs (450-550 $\mathrm{kg}$ ). They are capable of reaching speeds of over $40 \mathrm{mph}(64.4$ $\mathrm{kph}$ ) when travelling downhill in flat racing. In addition to propelling a jockey on to the ground from a saddle height of about 6 feet $(2 \mathrm{~m})$, horses can inflict injuries by biting, pulling, kicking, standing or rolling on the rider, and hitting the rider with a sudden movement of the head. ${ }^{10}$ When head injuries are considered, a value of 9 feet $(3 \mathrm{~m})$ is often used, being the distance between the rider's head and the ground. ${ }^{70}$ This review includes all injuries to jockeys during the course of a day's racing, not just those that occur between the start and finish of a race. Jockeys are at risk from the moment they come into contact with the horse (before mounting the horse in the paddock) until after they have dismounted and moved out of reach of the horse. About $30 \%$ of injuries occur in the paddock, before the start, in the stalls, or after the finish of a race.

It is worth emphasising that the jockey does not "sit" on the horse but rather grips the horse with knees, ankles, and thighs and leans forward over the horse's wither. The jockey's back is parallel to that of the horse. Because of this seating position, if the horse stops suddenly the jockey is usually propelled forward over its neck into the rail or on to the track and into the path of other horses. Riding in this position ("riding short") may also cause specific overuse soft tissue injuries. ${ }^{11}$

\section{Medical care of jockeys}

The Jockey Club closely regulates racing in Great Britain, and the medical arrangements on all racecourses must comply with a set of detailed instructions (The Jockey Club General Instruction 11 (JCGI l1)). A breach of these instructions is likely to result in action being brought against the racecourse by the regulating authority. A similar protocol has been developed for racing in Ireland.

At every race meeting, two appropriately trained doctors are required to be on duty solely to look after the needs of the jockeys. Separate medical care exists for injuries and illnesses in other attendees at race meetings (trainers, owners, stable staff, members of the public, etc). All jockeys carry a "medical passport" (Medical Record Book (MRB)), which is examined 
Table 5 Fatalities in professional horseracing in Great Britain 1975-2000

\begin{tabular}{lllll}
\hline Type of racing & Rides & Fatalities & M:F & $\begin{array}{l}\text { Fatality } \\
\text { rate* }\end{array}$ \\
\hline Flat racing & 953856 & 4 & $4: 0$ & 419.4 \\
Jump racing & 773511 & 5 & $4: 1$ & 646.4 \\
\hline
\end{tabular}

*Fatalitiy rate per 100000000 rides.

Table 6 Causes of death in professional horseracing in Great Britain 1975-2000

\begin{tabular}{|c|c|c|}
\hline $\begin{array}{l}\text { Case } \\
\text { number }\end{array}$ & Type of racing & $\begin{array}{l}\text { Cause of death (as listed on death } \\
\text { certificate) }\end{array}$ \\
\hline 1 & Flat & Cerebral laceration, skull fracture \\
\hline 2 & Jump & Left pneumothorax, lung laceration \\
\hline 3 & Jump (Amateur) & Cerebral oedema/haemorrhage \\
\hline 4 & Jump & Traumatic brain injury \\
\hline 5 & Jump & Subdural haematoma \\
\hline 6 & Flat & Intrathoracic haemorrhage/rib fractures \\
\hline 7 & Jump & Ruptured liver/inferior vena cava \\
\hline 8 & Flat (Amateur) & Subdural haematoma \\
\hline 9 & Flat & Subdural haematoma \\
\hline
\end{tabular}

by the racecourse authorities when the jockey arrives at a race meeting. All falls are recorded in the MRB and on a separate sheet (MO1), which is subsequently returned to the chief medical adviser of the licensing authority (Jockey Club or Turf Club). Since 1992, it has been compulsory for all racecourses to return a completed MOl form for every race meeting. All jockeys who fall, become ill, or are injured on a racecourse are required to report to a racecourse medical officer for examination. The results of all examinations must be recorded in the $\mathrm{MRB}$ and on the MOl form for return to the racing authority. Any jockey who has a recorded injury in his/her MRB (from a previous race meeting) may not return to race riding until she/he has been examined by a racecourse medical officer and declared "fit to return to race riding". This is then documented in the MRB.

The MOl system enables details of all falls and injuries to be maintained centrally and for injuries to be monitored by the chief medical advisor. This ensures that jockeys who are at additional risk (to themselves or of causing injury to other riders) are not allowed to return to competitive racing before it is safe for them to do so.

Professional jockeys in Great Britain are covered by an injury insurance scheme (Professional Riders Insurance Scheme) which provides weekly payments of up to $£ 1100$ for the injured jockey for up to a maximum of 78 weeks.

All jockeys are required to wear protective helmets to the European Standard EN 1384.1996, which must be securely fastened at all times. This standard became compulsory in Great Britain and Ireland in 1996, but helmets manufactured to this standard were available from 1993 and most jockeys in Great Britain were wearing them from 1994.

All jockeys are required to wear a body protector to the European Standard EN: 13158.2000; this became compulsory in 2001 . Jockeys have always been required to wear body protectors but there was considerable variety in construction before the adoption of the European Standard. Most jump jockeys have worn a "European type" body protector since 1994, but flat jockeys have tended to use a much lighter version with less protection. NB Body protectors are solely to reduce the incidence of fractured ribs and soft tissue injury. They were originally referred to as spinal protectors but they were never designed to fulfil this function. In essence, they are a padded vest with shoulder pads.

\section{METHODS}

The relevant literature was searched through the use of Medline (1966-2001) and Sport Discus (1975-2001) searches, manual searches of journals and reference lists, and discussions with experts and sporting organisations world wide. Keywords and Mesh headings used in all searches included horse racing, equestrian injuries, jockeys, concussion, brain injury, head injury, head trauma, brain trauma, sports injuries, and brain commotion.

The injury data were provided by the Jockey Club (for Great Britain statistics) and the Irish Turf Club (for the Republic of Ireland statistics) and is based on the medical evaluation of every fall that has occurred on a licensed racecourse during 1992-2000.

The injury definition used in this study is important. In many injury epidemiology studies, sporting injuries are defined as those causing time away from work or sports participation; however, horse racing is different. For example, amateur riders may only have four rides in a 12 month period and the fact that there may be a three month gap between races bears no relation to the injury severity. Professional jockeys tend to return to riding relatively quickly although in part this depends on the availability of rides rather than the fact that the injury is resolved. This is particularly true for younger or apprentice jockeys. For the purpose of this study an injury was therefore defined as one recorded in writing by the medical officer. It is acknowledged that this may result in under-reporting of the more minor injuries.

Data were statistically analysed using STATA 6.0.

\section{RESULTS}

This analysis of the injury data from Great Britain and Ireland involved a review of 745896 rides, 23525 falls, and 4248 injuries. Tables 1-3 show the injury epidemiology and incidence rates for the various forms of racing.

It can be seen that the injury incidence is significantly different between the two countries. In jump racing, the number of falls per ride and the injury rates per ride and per fall are higher in Great Britain than in Ireland. In flat racing, there is little difference between the two countries. In part, this may reflect the greater preponderance of jump racing in Ireland and presumably the greater experience of the jockeys concerned. There may also be under-reporting of minor injuries in Ireland which may in part explain the findings in table 3.

Another widely held belief is that the "best jump jockeys" get the "best horses" and are therefore less likely to fall and injure themselves. A subgroup analysis was performed of the top jump jockeys in Great Britain and Ireland (winning over 100 races per season in any of the last four jumps seasons). All these jockeys achieved a remarkable success rate of one win per 3.3-6.6 rides, with average winnings of £771 688 per jockey per season. There was no significant difference in the fall/ride ratio between these "elite" jump jockeys from the average fall/ride ratio of 16.0

\section{All weather turf racing and injuries}

There are three all weather tracks in Great Britain where flat races may be run during the winter months. All have a standard oval shaped track, but, unlike turf courses, the racing surface is a combination of sand, fibre, and a polymer binder designed not to freeze at subzero temperatures.

Table 4 gives injury data for 1994-2000 compared with similar data for turf flat racing. During that period, a total of 63163 rides, 175 falls, and 67 injuries were noted. Although the injury rates were higher on this surface, no particular types of injury were significantly increased.

\section{Fatal injuries}

Fatal injuries were extremely uncommon in 1992-2000. In flat racing, one death occurred in Great Britain and none in 
Table 7 Concussion rate per 100 falls 1992-2000

\begin{tabular}{llllllllllll}
\hline & 1992 & 1993 & 1994 & 1995 & 1996 & 1997 & 1998 & 1999 & 2000 & 2001 & Total \\
\hline Flat racing GB & 2.7 & 4.9 & 3.2 & 1.8 & 4.8 & 1.4 & 5.3 & 1.4 & 2.7 & 1.2 & 2.5 \\
Flat racing Ireland & - & 10.0 & 11.5 & 8.0 & 12.9 & 5.1 & 3.4 & 8.3 & 5.8 & 9.4 & 7.4 \\
Jump racing GB & na & 1.9 & 2.0 & 2.5 & 2.4 & 1.6 & 1.3 & 1.5 & 1.4 & 1.6 & 1.8 \\
Jump racing Ireland & 2.0 & 2.9 & 2.3 & 3.1 & 2.7 & 1.7 & 1.7 & 1.7 & 2.1 & 2.6 & 2.3 \\
\hline na, Not available. & & & & & & & & & & \\
\end{tabular}

Table 8 Common injuries to jockeys in flat racing in Great Britain and Ireland

\begin{tabular}{lllllllllll}
\hline & 1992 & 1993 & 1994 & 1995 & 1996 & 1997 & 1998 & 1999 & 2000 & Total \\
\hline Fracture & 9 & 7 & 12 & 4 & 11 & 7 & 8 & 8 & 7 & 64 \\
Dislocations & 0 & 0 & 0 & 0 & 2 & 0 & 0 & 0 & 0 & 2 \\
Concussion & 3 & 6 & 8 & 4 & 11 & 4 & 9 & 5 & 6 & 56 \\
Soft tissue injury & 36 & 31 & 58 & 51 & 53 & 68 & 43 & 80 & 48 & 468 \\
\hline
\end{tabular}

Table 9 Common injuries to jockeys in jump racing in Great Britain and Ireland

\begin{tabular}{lllllllllll}
\hline & 1992 & 1993 & 1994 & 1995 & 1996 & 1997 & 1998 & 1999 & 2000 & Total \\
\hline Fracture & 98 & 98 & 87 & 59 & 75 & 72 & 72 & 65 & 62 & 614 \\
Dislocations & 10 & 10 & 5 & 6 & 10 & 9 & 6 & 8 & 7 & 62 \\
Concussion & 57 & 62 & 53 & 64 & 67 & 44 & 38 & 45 & 34 & 419 \\
Soft tissue injury & 289 & 299 & 251 & 248 & 313 & 310 & 309 & 338 & 338 & 2433
\end{tabular}

Table 10 Injury rates in Great Britain 1992-2000

\begin{tabular}{|c|c|c|c|c|}
\hline \multirow[b]{2}{*}{ Injury } & \multicolumn{2}{|c|}{ Flat racing } & \multicolumn{2}{|c|}{ Jump racing } \\
\hline & $\begin{array}{l}\text { Injuri } \\
\text { falls }\end{array}$ & $\begin{array}{l}\text { Injuries per } 100000 \\
\text { rides }\end{array}$ & $\begin{array}{l}\text { Injurie } \\
\text { falls }\end{array}$ & $\begin{array}{l}\text { al Injuries per } 100000 \\
\text { rides }\end{array}$ \\
\hline Concussion & 2.8 & 11.6 & 1.84 & 125.6 \\
\hline Fracture & 3.6 & 14.6 & 2.55 & 174.2 \\
\hline Dislocations & 0.08 & 0.31 & 0.30 & 20.2 \\
\hline
\end{tabular}

Ireland. In jump racing, one occurred in Great Britain and none in Ireland. The cause of death was ruptured inferior vena cava and liver in one case and intrathoracic haemorrhage with multiple rib fractures and lung lacerations in the other.

In a more detailed analysis of horse racing deaths in Great Britain during 1975-2000 (26 years), there were 1727367 rides and eight deaths in flat and jump racing (table 5). Table 6 lists the cause of death for each case.

Deaths are normally expressed per 100000000 occasions (days) of participation, but on any given day a jockey may have between one and 12 rides, each of which exposes him/her to risk. The Jockey Club data are therefore expressed per 100000000 rides.

\section{Head injuries and concussion}

Concussion was a relatively common injury in this survey period (table 7). Although year to year variation occurred, in broad terms, the concussion rate was higher for flat racing. This reflects the higher speed and the fact that falls tend to occur when horses are closely bunched together so that jockeys sustain kicks from other horses, in addition to direct contact with the ground. It can also be seen that there is a geographic difference, with lower concussion rates in Great Britain than in Ireland in both flat and jump racing.

Other more severe head injuries occur. Three major head injuries were noted during the study period (two in flat racing, one in jumping). These were two extradural haemorrhages and one intracerebral bleed. All jockeys survived the incidents but none returned to race riding.

\section{Common injuries}

The most common injuries overall were soft tissue injuries. Because of variations in the reporting mechanisms between Great Britain and Ireland, it is likely that these injuries are under-reported. They included muscle contusions, ligament sprains, and muscle strains. Consistently, the injury resulting in the longest period off work was internal ligamentous derangement of the knee, with an average of 130 days off work. The most common serious injury experienced by jockeys was fracture (tables 8 and 9), mainly to the upper limb and clavicle (73\% in flat racing and $71 \%$ in jump racing). This is much higher than the $41 \%$ reported by Press et al ${ }^{12}$ for a similar set of jockeys.

A significant difference in injury rates between the two countries was also noted. The more serious injuries have been highlighted, as it is likely that they would be less subject to reporting bias (tables 10 and 11). It would appear that, although flat jockeys in Ireland have slightly fewer falls than those in Great Britain ( 1 fall/268 rides $v 1$ fall/240 rides), their chance of suffering a serious injury appears to be higher when flat racing in Ireland. When jump racing is considered, the fall/ride ratio is similar but the injury rates per ride are lower. 
Table 11 Injury rates in Ireland 1992-2000

\begin{tabular}{|c|c|c|c|c|}
\hline \multirow[b]{2}{*}{ Injury } & \multicolumn{2}{|l|}{ Flat racing } & \multicolumn{2}{|l|}{ Jump racing } \\
\hline & $\begin{array}{l}\text { Injuries as \% of total } \\
\text { falls }\end{array}$ & $\begin{array}{l}\text { Injuries per } 100000 \\
\text { rides }\end{array}$ & $\begin{array}{l}\text { Injuries as \% of total Ir } \\
\text { falls }\end{array}$ & $\begin{array}{l}\text { Injuries per } 100000 \\
\text { rides }\end{array}$ \\
\hline Concussion & 7.11 & 26.5 & 2.08 & 99.5 \\
\hline Fracture & 9.88 & 36.9 & 3.43 & 163.7 \\
\hline Dislocations & 0.40 & 1.47 & 0.25 & 11.7 \\
\hline
\end{tabular}

Table 12 Sport related deaths in England and Wales 1982-1999

\begin{tabular}{ll}
\hline Sport & Death rate* $^{*}$ \\
\hline Climbing/mountaineering (excluding hiking and fell walking) & $>793$ \\
Air sports & $>640$ \\
Motor sports & 146 \\
Water sports/windsurfing (excluding sailing and fishing) & 67.5 \\
Sailing/yachting & 44.5 \\
Fishing & 37.4 \\
Horse riding (excluding hunting and polo) & 34.3 \\
Rugby (union and league) & 15.7 \\
Boxing/wrestling & 5.2 \\
Soccer & 3.8 \\
Cricket & 3.1 \\
\hline \multirow{2}{*}{ *Deaths per 100000000 occasions (days) of participation. } & \\
\hline
\end{tabular}

The reasons for this regional difference are not clear but jockey expertise alone would not explain this pattern and it may be explained in part by under-reporting of minor injuries in Ireland. There is free flow of jockeys between the two countries, and there is no evidence from these riders that any difference exists in the standard or quality of racing in Great Britain and Ireland.

\section{Career ending injuries}

Career ending injuries were specifically analysed in the data from Great Britain. All these injuries have resulted in the maximum 78 week claim being paid by the insurance scheme outlined above. In the period 1996-2000, a total of 16 (13 jump, three flat) such injuries were noted. In the same period, a total of 300851 rides occurred with 8254 falls.

Injuries that ended the jockey's career included severe head injury (three cases), vertebral fracture (three cases), crushed hand (three cases), fractured elbow (two cases), fractured shoulder (two cases), ankle fracture (one case), knee ligament disruption (one case), and ruptured pancreas (one case).

\section{DISCUSSION}

There is a paucity of information on professional horse racing and the injury epidemiology within this sport. This is surprising given the high media and public interest in horse racing as a spectator sport. One of the difficulties is that many papers have been written on recreational and sporting equestrian participation rather than professional horse racing. ${ }^{3-5} 7^{13-38}$ There has also been considerable interest in equestrian injuries in paediatric and adolescent age groups. ${ }^{639-48}$ There is some information on the physiological demands of jockeys and in particular issues related to weight control and potential for medical problems. ${ }^{2}{ }^{49-57}$

Only a few studies on professional horse racing have been published. Many of these are case reports of serious injuries rather than injury epidemiology. ${ }^{1-3} 8{ }^{12} 50$ 58-65 As well as professional horse racing, there have been some studies on other forms of professional equestrian sport-for example, rodeo, fox hunting, and polo. ${ }^{31} 3266-69$

In the United States, Press et al ${ }^{12}$ reported a retrospective questionnaire study of 706 experienced professional jockeys and their injuries and health concerns. These jockeys ride an average of 600 races a year. In this study, a total of 1757 injuries were reported. Of these, fractures were the most common (64\% of total injuries) followed by concussion (8\%) and joint dislocation (7\%). Of the fractures, $41 \%$ were upper limb, $24 \%$ were lower limb, 12\% were rib fractures, $10 \%$ were spinal fractures, and 9\% were skull fractures, and 3\% were hip/pelvis fractures.

This differs from the findings in this study where most injuries were soft tissue, and upper limb/clavicle fractures predominated. This may in part be related to the surfaces on which horse racing occurs, but is more likely to be because jockeys take soft tissue injuries as part and parcel of everyday life and often omit details of them from any questionnaire of this sort. In America, the tracks are often dirt rather than turf and tend to be drier than British and Irish racetracks.

In another US retrospective survey of injuries occurring at a single racetrack in the 1970s, a total of 52 jockeys with 102 injuries were recorded over 4170 races. The average number of injuries per race was 0.024 , and most were soft tissue injuries. ${ }^{63}$ In this study, fractures and concussions were less common. Unfortunately the racing surface, medical care, and protective equipment in use at that time were not recorded.

More recent data from the United States suggests that the injury rates remain high, with about $20 \%$ being head or neck injuries and $20 \%$ being upper limb injuries. In a survey of about 2700 licensed jockeys, most injuries (42\%) were the result of being thrown from the horse or struck by the horse's head $(23 \%)$. Being thrown from the horse accounted for most of the severe injuries. Interestingly $35 \%$ of injuries occurred at the starting gate, including $30 \%$ of head injuries, $40 \%$ of upper limb injuries, and $52 \%$ of lower limb injuries. ${ }^{62}$

In another retrospective study from Berkshire in England, comparison was made between severe injuries sustained by both amateur and professional jockeys. ${ }^{8}$ In this study, 103 injured riders were surveyed, of which 32 were professional jockeys. In the group of professional jockeys, $37 \%$ of injuries were to the upper limb (of which, four were fractures), $26 \%$ were to the lower limb (three fractures), $11 \%$ were head injuries (one skull fracture), and 6\% were spinal injuries (no fractures). It was postulated that differences in injury profiles between amateur and professional jockeys were related to the 
use of protective equipment, more consistent racing surfaces, and "non-competitive" injuries. For example, in the amateur group, $25 \%$ of injuries occurred on public roads, usually where the horse reared or bolted when surprised by a passing vehicle.

Similar findings were noted in another study based on emergency department presentations in England. ${ }^{3}$ Amateurs were over-represented in the severe injuries; however, the small numbers of professional riders seen and the inherent selection bias make the interpretation of this study limited.

Limited data from the Jockey's Guild in North America also highlight specific problems. ${ }^{2}$ The Jockey's Guild Inc is a non-union trade association representing most jockeys in the United States. The Guild has over 1300 members. It estimates that more than 100 jockeys have died as a result of racing accidents since 1950, and five jockeys were killed between October 1988 and September 1991. In addition, 37 jockeys were permanently disabled from spinal cord injuries in racing mishaps. ${ }^{2}{ }^{12}$ In the present study, relatively few spinal cord injuries were noted. This difference is not clearly explained by the available data.

In extensive reviews of injuries associated with horse riding, Bixby-Hammett et a $l^{14}{ }^{15}$ and others ${ }^{2460} 70-72$ found that deaths accounted for less than $1 \%$ of all injuries, although some studies, derived from neurological units, report high numbers of such injuries. Similar findings are noted in this study, with only two deaths recorded in the nine year time frame and a total of nine deaths over a 26 year period of data collection.

The Sheffield study ${ }^{73} 74$ provides an analysis of 799 sporting fatalities involving participants aged $15+$ in England and Wales (1982-1989) (table 12). These data excluded all deaths from "natural causes" such as coronary artery disease.

To provide a comparison with these values, it is necessary to convert the Jockey Club data from "rides" to "participant occasions". Over the 26 years 1975-2000, there was an average of 23 jockeys in attendance at each flat race meeting and 25 jockeys for each jump race meeting. This in turn would mean that comparative values for race fatalities would be as follows. For flat racing, there were four deaths in 13846 race meetings or 1256 deaths per 100000000 participant occasions. For jump racing, there were five deaths in 13076 race meetings or 1529 deaths per 100000000 participant occasions. This indicates that race riding in Great Britain is 58-93\% more dangerous (in terms of fatal incidents) than climbing/ mountaineering, the most dangerous sport identified by the Sheffield Study.

With regard to non-fatal equestrian injuries in nonprofessional competitors, the most common injuries are soft tissue injuries (range 1-92\%) followed by fractures (4-57\%) and concussion (4-66\%). It is worth noting that the definition of concussion varies considerably in the reported studies, which may account for wide variations in injury incidence. ${ }^{15}$

The use of protective equipment is important. As professionals in a high risk occupation, it is sensible to use protective equipment to minimise both injuries and time off work. At present, the use of helmets and body protectors is mandatory.

It is recommended that an approved safety helmet be worn at all times when mounted. ${ }^{75}$ The coverage of the helmet is critical, with some studies suggesting that occipital fractures are most common, ${ }^{70}{ }^{76}$ whereas another suggested that parietal fractures are the major risk. ${ }^{8}$ The British standard for riding helmets (EN 1384.1996) is designed for all forms of equestrian sport and is compulsory for professional jockeys. ${ }^{77}$ Similar standards for horse riding helmets exist in other countries. Interestingly, since this design of helmet was made compulsory in 1993/1994, no significant changes in concussion rates have been observed. The numbers of fatal brain injuries are too small to be adequately analysed in this regard.

Indirect evidence exists that head protectors may play a role in injury reduction, at least in amateurs. Data from the emergency services in Oxford, England showed a fivefold reduction

\section{Take home message}

The spectrum of injury in horse racing includes fractures, head injuries (minor and major), dislocations, and deaths. Because of the forces involved, personal protective equipment can only hope to mitigate some of these injuries. Those providing medical cover at such events should be fully aware of the risks involved, be suitably trained and qualified to carry out their duties, and have immediate access to the appropriate equipment and drugs to manage acute, life threatening trauma.

in horse related injury presentations between 1971 and 1992 This change was largely due to a reduction in head injury presentation. This was associated with an increase in helmet use. ${ }^{16}$ Similar findings were noted in a paediatric study from Virginia. ${ }^{41}$ Strategies to increase helmet use in riders have been extensively studied. ${ }^{15} 78$

Body protectors, or safety vests, protect the trunk principally against soft tissue injuries and rib fractures. It will not protect the spinal column from compressive injuries nor against a massive crushing blow to the chest. This item weighs about $1 \mathrm{~kg}$ and its use is compulsory. The European Standard for these items is EN 13158.2000, and body protectors are compulsory in Great Britain and Ireland. The effectiveness of this item remains to be tested scientifically, and, despite the fact that they have been in use for 20 years, a uniform, international standard has only just been introduced. Prospective data will need to be followed over time.

\section{Conclusion}

Horse racing is an exciting sport with a high risk of injury. Jump racing has significantly higher injury rates than flat racing, particularly in relation to upper limb fractures and concussion. In addition, there are notable geographic variations in injury rates, with jump jockeys in Ireland falling less often and sustaining fewer injuries than those riding in Great Britain. Although fatal injuries are relatively uncommon, the incidence per days of participation is strikingly high when compared with other sports. The introduction of protective equipment has been an important safety measure, although at this stage no conclusive data are available on the effectiveness of head or body protectors conforming to the relevant European Standard. The improvement in medical regulation and the development of injury management guidelines in both Great Britain and Ireland has enabled the collection of accurate injury information, which in turn may be used in injury prevention programmes.

\section{ACKNOWLEDGEMENTS}

Special thanks are due to Kate O'Neill and the other staff at The Jockey Club for their patience in answering endless questions. Our thanks also go to Mrs Elizabeth Meredith of the Irish Turf Club for providing the Irish data for comparison.

\section{Authors' affiliations}

M Turner, Jockey Club, 42 Portman Square, London W1H 6EN, UK P McCrory, Centre for Sports Medicine Research \& Education and Brain Research Institute, University of Melbourne, Parkville, Victoria, Australia 3052

W Halley, The Turf Club, The Curragh, County Kildare, Eire

\section{REFERENCES}

1 Fletcher J, Davies PT, Lewis T, et al. Traumatic carotid and vertebral artery dissection in a professional jockey: a cautionary tale. Br J Sports Med 1995;29:143-4.

2 DeBenedette V. For jockeys, injuries are not a long shot. Physician and Sports Medicine 1987; 15:237-45. 
3 Lloyd RG. Riding and other equestrian injuries: considerable severity. $\mathrm{Br}$ J Sports Med 1987;21:22-4.

4 Masters R. Equestrian injuries: a review. Clin J Sports Med $1991 ; 1: 123-6$

5 McLatchie GR. Equestrian injuries: a one year prospective study. $\mathrm{Br} J$ Sports Med 1979;13:29-32.

6 Nelson DE, Bixby-Hammett D. Equestrian injuries in children and young adults. American Journal of Diseases in Children 1992;146:611-14.

7 Nelson D, Rivara F, Condie C, et al. Injuries in equestrian sports. Physician and Sports Medicine 1994;22:53-60.

8 Whitlock MR, Whitlock J, Johnston B. Equestrian injuries: a comparison of professional and amateur injuries in Berkshire. Br J Sports Med 1987;21:25-6

9 Whitlock MR. Injuries to riders in the cross country phase of eventing: the importance of protective equipment. Br J Sports Med 1999;33:212-14.

10 Regan P, Roberts J, Feldberg L, et al. Hand injuries from leading horses Injury 1991;22:124-6.

11 Lavelle J, Murphy J. Jockey's ankle: an occupational lesion. J Ir Med Assoc 1977;70:282.

12 Press JM, Davis PD, Wiesner SL, et al. The national jockey injury study: an analysis of injuries to professional horse-racing jockeys. Clin J Sport Med 1995;5:236-40.

13 Barclay WR. Equestrian sports. JAMA 1978;240:1892-3.

14 Bixby-Hammett DM. Accidents in equestrian sports. Am Fam Physician 1987;36:209-14.

15 Bixby-Hammett D, Brooks WH. Common injuries in horseback riding. A review. Sports Med 1990;9:36-47.

16 Chitnavis JP, Gibbons CL, Hirigoyen M, et al. Accidents with horses: what has changed in 20 years? Injury 1996;27:103-5.

17 Douglas BL. Oral protection for equestrians. CDS Rev 1995;88:28-30

18 Greiss FC, Jr. Equestrian dyspareunia. Am J Obstet Gynecol 1984; 150:168

19 Grossman JA, Kulund DN, Miller CW, et al. Equestrian injuries. Results of a prospective study. JAMA 1978;240:1881-2.

20 Hobbs GD, Yealy DM, Rivas J. Equestrian injuries: a five-year review. J Emerg Med 1994; 12:143-5.

21 Hughes KM, Falcone RE, Price J, et al. Equestrian-related trauma. Am J Emerg Med 1995;13:485-7.

22 Kriss TC, Kriss VM. Equine-related neurosurgical trauma: a prospective series of 30 patients. J Trauma 1997;43:97-9.

23 O'Farrell DA, Irshad F, Thorns BS, et al. Major pelvic injuries in equestrian sports. Br J Sports Med 1997;31:249-51

24 Pounder DJ. "The grave yawns for the horseman." Equestrian deaths in South Australia 1973-1983. Med J Aust 1984;141:632-5.

25 Reich L. [Head and neck injuries in equestrian accidents.] (Authors' translation). HNO 1979;27:416-18.

26 Buckley S, Chalmers D, Langley J. Injuries due to falls from horses. Australian Journal of Public Health 1993;17:269-71.

27 MMWR. Horseback riding associated traumatic brain injury, Oklahoma 1992-1994. MMWR Morb Mortal Wkly Rep 1996;45:209-1 1.

28 Ingermarson $\mathbf{H}$, Grevsten S, Thoren L. Lethal horseriding injuries. J Trauma 1989;29:25-30.

29 Hume P, Marshall S. Sports injuries in New Zealand. New Zealand Journal of Sports Medicine 1994;22:18-22.

30 Silver J, Parry J. Hazards of horse riding as a popular sport. Br J Sports Med 1991;25:105-10.

31 Costa-Paz M, Aponte-Tineo L, Muscolo D. Injuries to polo riders: a prospective evaluation. Br J Sports Med 1999;33:329-32.

32 Butterwick D, Nelson D, LaFave $M$, et al. Epidemiological analysis of injury in one year of Canadian professional rodeo. Clin J Sports Med 1996;6:171-7.

33 DeBenedette V. People and horses: the risks of riding. Physician and Sports Medicine 1989:17:251-5.

34 Bernhang A, Winslett G. Equestrian injuries. Physician and Sports Medicine 1983;11:90-7.

35 Gierup J, Larsson $M$, Lennqvist $S$. Incidence and nature of horse riding injuries. Acta Chir Scand 1976;142:57-61

36 Lando L. Riding injuries stir British concern. Physician and Sports Medicine 1976;4:124-6.

37 Rathfelder F, Klever P, Nachtkamp J, et al. Injuries in horseback riding: incidence, frequency and causes. Sportverletz Sportschaden 1995;9:77-83

38 CDC. Injuries associated with horseback riding, United States 1987/8. JAMA 1990;264:18-19.

39 Barone GW, Rodgers BM. Pediatric equestrian injuries: a 14-year review. J Trauma 1989;29:245-7.

40 Bixby-Hammett DM. Pediatric equestrian injuries. Pediatrics 1992:89:1173-6.

41 Bond GR, Christoph RA, Rodgers BM. Pediatric equestrian injuries: assessing the impact of helmet use. Pediatrics 1995;95:487-9.
42 Campbell-Hewson GL, Robinson SM, Egleston CV. Equestrian injuries in the paediatric age group: a two centre study. Eur J Emerg Med 1999;6:37-40.

43 Christey GL, Nelson DE, Rivara FP, et al. Horseback riding injuries among children and young adults. J Fam Pract 1994;39:148-52.

44 Giebel G, Braun K, Mittelmeier W. [Equestrian accidents in children]. Chirurg 1993;64:938-47.

45 McAbee GN, Ciminera PF. Intracranial hematoma in experienced teenage equestrians. Pediatr Neurol 1996;15:235-6.

46 Reeder Al, Stanton WR, Langley JD, et al. Adolescents' sporting and leisure time physical activities during their 15th year. Can J Sport Sci $1991 ; 16: 308-15$

47 Schmidt B, Mayr J, Fasching $G$, et al. [Equestrian accidents in children and adolescents]. Unfallchirurg 1994;97:661-2.

48 Sahlin Y. Sports accidents in childhood. Br J Sports Med 1990;24:40-4.

49 King MB, Mezey G. Eating behaviour of male racing jockeys. Psychol Med 1987; 17:249-53.

50 Labadarios D, Kotze J, Momberg D, et al. Jockeys and their practices in South Africa. World Rev Nutr Diet 1993;71:97-1 14.

51 Meyers MC, Sterling JC. Physical, hematological, and exercise response of collegiate female equestrian athletes. J Sports Med Phys Fitness 2000;40:131-8.

52 Price D. Abuse of diuretics by jockeys. BM 1973;1:804

53 Simonetti C, Lupoi D, Di Giambattista G, et al. [Biomechanical changes in and lesions of the lumbosacral spine in horse riding. Magnetic resonance assessment]. Radiol Med (Torino) 1996;91:542-6.

54 Trowbridge EA, Cotterill JV, Crofts CE. The physical demands of riding in National Hunt races. Eur J Appl Physiol Occup Physiol 1995;70:66-9.

55 Turner L. Against all odds. Medical providers keep watch as jockeys be their health on winning rides. J Ark Med Soc 2000;96:366-9.

56 Fann T. Can the bionic jockey be far behind? Spur 1983;Mar/Apr:249.

57 Lockey A, Downing R. An unusual complication of major trauma in a jockey. Injury 1997;28:413-14.

58 Andermahr J, Schiffer G, Burger C, Rehm KE. [Spinal injuries in jockeys. 2 case reports and review of the literature]. Unfallchirurg 2000; 103:688-92

59 d'Abreu F. Brain damage in jockeys [letter]. Lancet 1976;1:1241.

60 Foster JB, Leiguarda R, Tilley PJ. Brain damage in National Hunt jockeys. Lancet 1976;1:981-3.

61 Middleton SB, Foley SJ, Foy MA. Partial excision of the clavicle for nonunion in National Hunt Jockeys. J Bone Joint Surg $[\mathrm{Br}]$ 1995;77:778-80.

62 Waller AE, Daniels JL, Weaver NL, et al. Jockey injuries in the United States. JAMA 2000;283:1326-8.

63 Whitesel J. How Jockeys get hurt in thoroughbred racing. Physician and Sports Medicine 1976;4:67-9

64 Allen M. Medical aspects of horse racing. Sports Therapy 1992;3:10-11

65 Patel J, Turner M, Birch R, McCrory P. Rupture of the axillary (circumflex) nerve and artery in a champion jockey. Br J Sports Med $2001 ; 35: 361-4$

66 Griffin R, Peterson K, Halseth J. Injuries in professional rodeo. Physician and Sports Medicine 1984;12:130-7.

67 Sankaran-Kutty M, Abu Baker A. The camel jockey's tibial fracture. Injury 1994;25:155-7.

68 Aspergen D, Keller R. Injuries in the Turquoise professional rodeo circuit in 1994. Chiropractic and Sports Medicine 1995;9:94-6.

69 Butterwick D, Meeuwisse W. Effect of experience on rodeo injury. Clin J Sport Med 2002;12:30-6.

70 McGee C, Gullan R, Miller J. Horse riding and head injury. $\mathrm{Br} J$ Neurosurgery 1987;1:131-6.

71 Aronsen H, Trough S. Horse-related fatalities in the Province of Alberta, 1975-1990. Am J Forensic Med Pathol 1993:14:28-30.

72 Hamilton M, Tranmer B. Nervous system injuries in horseback riding accidents. J Trauma 1993;34:227-32.

73 Nicholl J, Coleman P, Williams B. Injuries in sport and exercise. London Medical Care Research Unit and Sports Council, 1991: Report no. ISBN 1-872158-71-4.

74 Nicholl J, Coleman P, Williams B. The epidemiology of sports and exercise related injury in the United Kingdom. Br J Sports Med 1995;29:232-8.

75 Nelson D, Rivara F, Condie C. Helmets and horseback riders. Am J Prev Med 1994;10:15-9.

76 Bixby-Hammett D, Brooks WH. Prevention of neurologic injuries in equestrian sports. Physician and Sports Medicine 1988;16.

77 Mills N, Whitlock M. Performance of horse riding helmets in frontal and side impacts. Injury 1989;20: 189-92.

78 Condie C, Rivara FP, Bergman AB. Strategies of a successful campaign to promote the use of equestrian helmets. Public Health Rep 1993; 108:121-6. 